\title{
Structure analysis and study of sticky and waterish material dryer
}

\author{
Xinqi Yu ${ }^{1, a}$, Dongdong Yuan ${ }^{1, b}$, Guanghui Peng ${ }^{2, c}$, Qinggang Liu ${ }^{1, d}$, \\ Zhao Zhang ${ }^{1, e}$, Bin Zhang ${ }^{2, f}$ \\ ${ }^{1}$ School of Mechanical Engineering, Hebei University of Science and Technology, 26 Yuxiang \\ Avenue, Shijiazhuang 050018 \\ ${ }^{2}$ Shijiazhuang Newthreetalent Engineering Ltd, 136 Jianhua South Avenue, Shijiazhuang 050018 \\ ayxqyxq0016@163.com, byddd520@sina.com, ${ }^{\mathrm{c}}$ pengguanghui_1976@163.com,

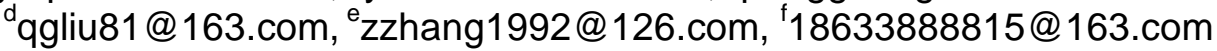

\begin{abstract}
Keywords: Sticky and waterish material, Tossing mechanism, Hot air distribution system, Thermal convection and conduction, Hydrolysis of Pan-sodium salt

Abstract. In this paper, a new pattern sticky and waterish material dryer mainly consists of tossing mechanism, hot air distribution system, and feeding and discharging device. Material is scraped off and crushed by tossing mechanism with high speed rotating spiral sheets. Hot air is redistributed to improve the efficiency of heat and mass transfer by hot air distribution system with blower turbofan. Heat transfer of thermal convection and conduction is adopted in this dryer. The drying test for Hydrolysis of Pan-sodium salt is conducted respectively by diffierent dryers. The test shows that the new pattern sticky and waterish material dyer has the advantages of high effiency, low power consumption, non-pollution and automatic continuous production.
\end{abstract}

\section{Introduction}

Drying sticky and waterish material is always a problem of drying industry for its high viscosity of millions of cp and high humidity of over $50 \%$. The material can be defined as Non-Newtonian fluid, as it is pasty, difficult to transport and hard to form, extract and granulate. In the process of drying, a seal film can easily form on the surface of the material, making it hard for water to evaporate, which leads to difficulty of drying. Currently, the problems of low efficiency, limited range and sticky shaft lie in drying sticky and waterish material of oven dryer, horizontal stirring dryer, fluidized bed dryer, drum dryer and rotary vane dryer in production [1-4]. A new pattern sticky and waterish material dryer is developed in order to solve the problems above.

\section{Overall structure and working principle}

As shown in fig.1, the dryer is mainly composed of tossing mechanism, hot air distribution system, and feeding and discharging device. Tossing mechanism is made up of spindle 1, spindle head cooling system 2 and spiral blade 4 . Hot air distribution system consists of blower turbofan 3 , inlet 6 , outlet 9 , and jacket 10. Feeding and discharging device is composed of feeding device 5, discharging rake 7 and discharging device 9. This dryer is a vertical dryer, which has advantages of small footprint, wide range of drying material.

Hot air flows horizontally into the area of jacket, after which it rises from the bottom of the dryer towards the upper areas, heating the inner cylinder of jacket. The hot air uniformly distributed by the blower turbofan goes into the inner cylinder and transfers heat to wet material. Moisture inside material evaporates fast and is later taken away by the hot air through outlet 9. Meanwhile, the material is driven into the inner cylinder 10 by feeding device 5 , after which scraped off by high speed spiral blade 4 rotating with belt wheel 8 . With powerful centrifugal force, the material is crushed into small pieces evenly distributed. At that time, a thin film layer of the material is formed on the inner wall fully contacted with hot air and hot wall. Material is scraped, crushed, dispersed and hit into small pieces or powder by spiral sheets forms. After the process, the small pieces or powder are discharged from discharging outlet 9 to collecting device and cyclone separator by discharging rake 7 to become 
qualified dry product. A combination heat transfer of convection and conduction is achieved in the process of drying.

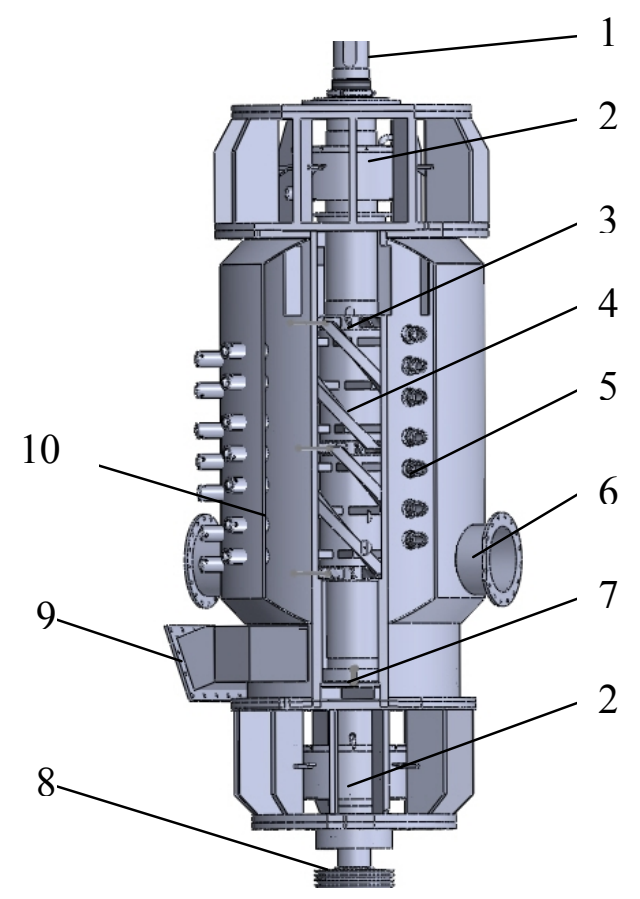

Fig.1 Structure of the new pattern sticky and waterish material dryer

1-Spindle; 2-Spindle head cooling system; 3-Blower turbofan; 4-Spiral blade; 5-Feeding device; 6-Air inlet; 7-Discharging rake; 8-Belt wheel; 9-Air outlet/Discharging device; 10-Jacket

\section{Tossing mechanism}

Tossing mechanism consists of spindle, spindle head cooling system and spiral blade. As shown in Fig.2, spiral blade is the core component of the dryer tossing mechanism which is composed of inner sleeve 1, supporting arm 2 and spiral sheet 3 . Spiral sheets, which have a $60^{\circ}$ angle with the horizontal level, are fastened by multiple supporting arms. Material is scraped on the inner cylinder by spiral sheets rotating with high speed spindle $\left(900-1440 \mathrm{~min}^{-1}\right)$. Meanwhile, material in the inner cylinder is scraped off completely and crushed into small pieces or dry powder within $0.1-1 \mathrm{~s}$, as the result of the narrow space of less than $1 \mathrm{~mm}$ between spiral and inner cylinder wall.

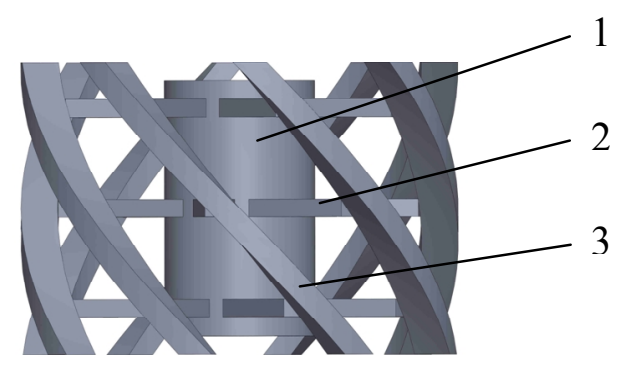

Fig. 2 Spiral balde

1-Inner sleeve; 2-Supporting arm; 3-Spiral sheet

Composed of spraying pipe 1, supporting plates 2, collection tank 3 and outlet pipe 4, Spindle head cooling system is the auxiliary components of tossing mechanism, as shown in Fig.3. The spindle and spiral blade are connected by hollow shaft. Since the operating temperature is up to $400{ }^{\circ} \mathrm{C}$, cooling system is needed for the structure. Cold water is sprayed onto solid shaft and cooling spindle head to ensure a proper operating temperature for bearings. What's more, used water will be recycled later to save energy. 


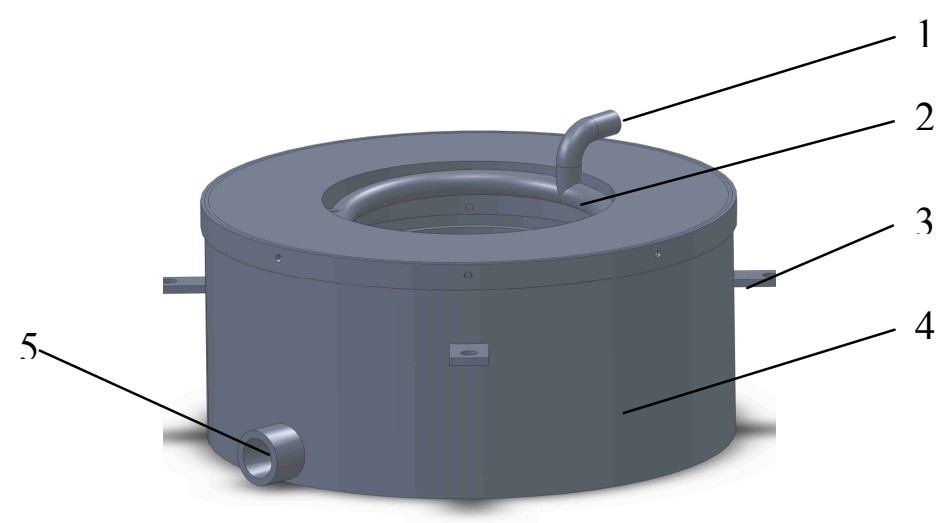

Fig. 3 Spindle head cooling system

1-Water inlet; 2- Spraying pipe; 3-Supporting plate; 4-Collection tank; 5-Water outlet

\section{Hot air distribution system}

Hot air distribution system is composed of blower turbofan, air inlet, air outlet and jacket. Four air inlets are arranged on the dryer jacket to guarantee the hot air to be distributed uniformly and the inner cylinder to be heated. The hot air rises from the bottom of the dryer and flows through the top of the inner cylinder.

Blower turbofan is the core of the hot air distribution system, as shown in Fig.4. Blower turbofans are used to rearrange uneven hot air of the top of inner cylinder so that all crushed materials can be evenly heated to improve drying efficiency. There are 3 blower turbofans mounted on the spindle, respectively located on the upper, middle and lower part of the spiral blade. Each blower turbofan has 20-24 blades which is of spiral-shaped structure with a $45^{\circ}-60^{\circ}$ angle to the horizontal level.

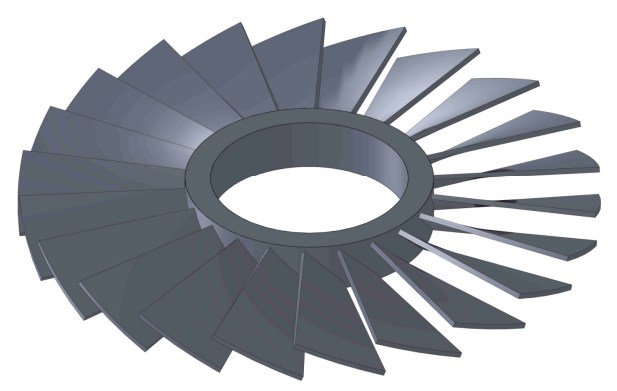

Fig.4 Blower turbofan

\section{Feeding and discharging device}

Feeding device is shown in Fig. 1. In order to preheat and dry the material by hot air uniformly, 50 to 60 feeding pipes are distributed uniformly in 6 to 8 columns with adjacent columns staggered on jacket. The lift of valve set is controlled to reach the expected effect.

The material dried is discharged through discharging outlet 9 (as air outlet) powered by discharging rake7, as shown in Fig.1.

\section{Experimental study}

The test material is Hydrolysis of Pan-sodium salt with $2640000 \mathrm{cp}$ viscosity and $75 \%$ humidity. As is shown in Table 1, the drying test is conducted respectively using oven dryer, drum dryer, new pattern sticky and waterish material dryer. 
Table 1. Drying test result

\begin{tabular}{|c|c|c|c|}
\hline & Oven dryer & Drum dryer & New pttern dryer \\
\hline Production & $3.5[\mathrm{t} /$ oven] & $1[\mathrm{t} / \mathrm{drum}]$ & $10[\mathrm{t} / \mathrm{each}]$ \\
\hline Operating mode & $\begin{array}{c}\text { Manual intermittent } \\
\text { control }\end{array}$ & $\begin{array}{c}\text { Manual intermittent } \\
\text { control }\end{array}$ & $\begin{array}{c}\text { Automatism and } \\
\text { continuous procduction }\end{array}$ \\
\hline Production & $111[\mathrm{~kW}]$ & $10[\mathrm{t} / \mathrm{day}]$ \\
\hline Power consumption & $40 \%$ & $197[\mathrm{~kW}]$ & $185.5[\mathrm{~kW}]$ \\
\hline Drying effiency & $1.4[\mathrm{t} / \mathrm{t}]$ & $60 \%$ & $82 \%$ \\
\hline $\begin{array}{c}\text { Coal consumption/ } \\
\text { Per production }\end{array}$ & $\begin{array}{c}\text { There is no equipment } \\
\text { for exhaust gas } \\
\text { Environmental } \\
\text { protection }\end{array}$ & $\begin{array}{c}\text { Difficulty in vapor } \\
\text { recovery } \\
\text { gas smell awful }\end{array}$ & $\begin{array}{c}\text { Exhaust gas can be } \\
\text { focused on recycling } \\
\text { through cyclone } \\
\text { separator }\end{array}$ \\
\hline
\end{tabular}

From Table 1, it can be concluded that the new pattern sticky and waterish material dyer has the advantages of high effiency, low power consumption, non-pollution and automatic continuous production.

\section{Conclusion}

The new pattern sticky and waterish material dryer adopts spiral blade to assume material to be dried and free from sticky shaft. Blower turbofan is able to evenly distribute hot air, improving the efficiency of energy. Spindle head cooling system is the key to ensuring a long operating duration of the spindle. Evenly arranged feeding pipes are capable of improving drying efficiency. Analysis and test show that the new pattern sticky and waterish material dryer has advantages of high drying efficiency, safety, less power consumption, fast drying, easily operation and widely application.

\section{References}

[1] L.Q. Huang, G.H. Peng: The second session of the conference and Chinese drying technology professional group chemical equipment hundred Conference. Vol.10(2010), p. 48

[2] G.W. Liu, Drying equipment design manual, China Machine Press, Beijing, 2009.

[3] Y.K. Pan, X.Z. Wang, X.D. Liu, Modern Drying Technology, Chemical Industry Press, Beijing, 2006.

[4] J.M. Yang: Petrochemical Equipment. Vol. 10(2010), p. 36 